\title{
Gender differences in the association of gene polymorphisms with type 2 diabetes mellitus
}

\author{
SACHIYO YAMAGUCHI ${ }^{1}$, YOSHIJI YAMADA ${ }^{1,2}$, HITOSHI MATSUO $^{3}$, TOMONORI SEGAWA ${ }^{3}$, \\ SACHIRO WATANABE ${ }^{3}$, KIMIHIKO KATO ${ }^{4}$, KIYOSHI YOKOI $^{4}$, SAHOKO ICHIHARA $^{1}$, \\ NORIFUMI METOKI ${ }^{5}$, HIDEMI YOSHIDA ${ }^{6}$, KEI SATOH ${ }^{6}$ and YOSHINORI NOZAWA ${ }^{2}$
}

\begin{abstract}
${ }^{1}$ Department of Human Functional Genomics, Life Science Research Center, Mie University, Tsu; ${ }^{2}$ Gifu International Institute of Biotechnology, Kakamigahara; ${ }^{3}$ Department of Cardiology, Gifu Prefectural Gifu Hospital, Gifu; ${ }^{4}$ Department of Cardiovascular Medicine, Gifu Prefectural Tajimi Hospital, Tajimi; ${ }^{5}$ Department of Internal Medicine, Hirosaki Stroke Center; ${ }^{6}$ Department of Vascular Biology, Institute of Brain Science, Hirosaki University School of Medicine, Hirosaki, Japan
\end{abstract}

Received December 11, 2006; Accepted January 22, 2007

\begin{abstract}
Type 2 diabetes mellitus is a complex metabolic disorder in which endogenous sex hormones may contribute to sex-dependent etiologies. We hypothesized that genetic variants related to type 2 diabetes mellitus might differ between men and women. We thus performed a large-scale association study to identify gene polymorphisms associated with type 2 diabetes mellitus in men and women separately. The study population comprised 4854 unrelated Japanese individuals (2688 men, 2166 women), including 1490 subjects with type 2 diabetes mellitus (969 men, 521 women). The genotypes for 16 gene polymorphisms were determined with a method that combines the polymerase chain reaction and sequence-specific oligonucleotide probes with suspension array technology. Multivariable logistic regression analysis with adjustment for age, body mass index, and smoking status revealed that the $\mathrm{T} \rightarrow \mathrm{G}\left(3^{\prime} \mathrm{UTR}\right)$ polymorphism of the thrombospondin 2 gene (THBS2), the $-603 \mathrm{~A} \rightarrow \mathrm{G}$ polymorphism of the coagulation factor III gene $(F 3)$, and the $\mathrm{G} \rightarrow \mathrm{T}$ (intron 2 ) polymorphism of the adipocyte, $\mathrm{C} 1 \mathrm{Q}$, and collagen domain containing (adiponectin) gene $(A D I P O Q)$ were significantly associated with the prevalence of type 2 diabetes mellitus in men, and that the $\mathrm{A} \rightarrow \mathrm{G}$ (Arg160Gly) polymorphism of the paraoxonase 1 gene (PON1) was significantly associated with this condition in women. A stepwise forward selection procedure demonstrated that genotypes of THBS2, F3, and $A D I P O Q$ were significant determinants of type 2 diabetes mellitus in men, and that genotype of PON1 significantly affected this condition in women. Genotyping of these polymorphisms may prove informative for assessment of the
\end{abstract}

Correspondence to: Dr Yoshiji Yamada, Department of Human Functional Genomics, Life Science Research Center, Mie University, 1577 Kurima-machiya, Tsu, Mie 514-8507, Japan

E-mail: yamada@gene.mie-u.ac.jp

Key words: diabetes mellitus, genetics, polymorphism, sex difference genetic component of type 2 diabetes mellitus for men and women separately.

\section{Introduction}

Diabetes mellitus has reached epidemic proportions and affects more than 170 million individuals worldwide (1). A global estimate predicts further growth of almost $50 \%$ in the prevalence of this condition by 2010 (2). More than $90 \%$ of diabetic individuals have type 2 diabetes mellitus, the characteristics of which can range from predominant insulin resistance with relatively minor insulin deficiency to predominant insulin deficiency with relatively minor insulin resistance (3). Several mechanisms have been proposed for the pathogenesis of type 2 diabetes mellitus, including an increase in the production of nonesterified fatty acids, inflammatory cytokines, or adipokines or dysfunction of mitochondria for insulin resistance, and glucotoxicity, lipotoxicity, and amyloid formation for ß-cell dysfunction (1). Although a sedentary lifestyle and overeating appear to be triggering factors, genetic components are also implicated in the pathogenesis of type 2 diabetes mellitus, given that a positive family history confers a 2.4-fold increased risk for this condition (1).

The amount and distribution of body fat differ among ethnic groups and between the sexes. Men have less overall body fat but a greater amount of abdominal fat than do women of the same body mass index (BMI). Abdominal fat, particularly visceral (intraabdominal) fat, is a strong negative predictor of insulin sensitivity, but the relation between regional abdominal fat and insulin sensitivity differs between men and women (4). Endogenous sex hormones may play a role in sex-dependent etiologies of type 2 diabetes mellitus. A meta-analysis suggested that the endogenous levels of testosterone and sex hormone-binding globulin each exhibit a sex-dependent relation to the risk of type 2 diabetes (5). These observations suggest the importance of investigating sex-specific etiologies of type 2 diabetes mellitus.

Although genetic linkage analyses (6-10) and association studies (11-15) have implicated several loci and candidate 
Table I. Characteristics of the male and female subjects.

\begin{tabular}{|c|c|c|c|c|c|c|}
\hline \multirow[b]{2}{*}{ Characteristic } & \multicolumn{3}{|c|}{ Men } & \multicolumn{3}{|c|}{ Women } \\
\hline & $\begin{array}{c}\text { Type } 2 \\
\text { diabetes mellitus }\end{array}$ & Controls & $\mathrm{P}$ & $\begin{array}{c}\text { Type } 2 \\
\text { diabetes mellitus }\end{array}$ & Controls & $\mathrm{P}$ \\
\hline No. of subjects & 969 & 1719 & & 521 & 1645 & \\
\hline Age (years) & $62.7 \pm 11.3$ & $63.7 \pm 11.5$ & 0.0285 & $65.6 \pm 11.7$ & $63.9 \pm 12.1$ & 0.0040 \\
\hline Smoking (\%) & 29.4 & 28.3 & 0.5310 & 4.8 & 3.5 & 0.1982 \\
\hline Body mass index $\left(\mathrm{kg} / \mathrm{m}^{2}\right)$ & $23.8 \pm 3.2$ & $23.2 \pm 2.6$ & $<0.0001$ & $23.6 \pm 3.6$ & $23.4 \pm 3.0$ & 0.2960 \\
\hline Systolic blood pressure (mmHg) & $148 \pm 26$ & $141 \pm 27$ & $<0.0001$ & $149 \pm 31$ & $138 \pm 28$ & $<0.0001$ \\
\hline Diastolic blood pressure (mmHg) & $81 \pm 15$ & $78 \pm 15$ & 0.0001 & $80 \pm 17$ & $77 \pm 15$ & $<0.0001$ \\
\hline Serum total cholesterol (mmol/l) & $5.38 \pm 1.10$ & $5.16 \pm 0.96$ & $<0.0001$ & $5.60 \pm 1.14$ & $5.24 \pm 0.91$ & $<0.0001$ \\
\hline Serum triglycerides (mmol/l) & $1.86 \pm 1.37$ & $1.54 \pm 1.04$ & $<0.0001$ & $1.67 \pm 0.96$ & $1.35 \pm 0.76$ & $<0.0001$ \\
\hline Serum HDL-cholesterol (mmol/l) & $1.19 \pm 0.35$ & $1.30 \pm 0.38$ & $<0.0001$ & $1.41 \pm 0.36$ & $1.52 \pm 0.33$ & $<0.0001$ \\
\hline Fasting plasma glucose (mmol/l) & $10.31 \pm 4.43$ & $5.23 \pm 0.66$ & $<0.0001$ & $9.96 \pm 4.41$ & $5.15 \pm 0.68$ & $<0.0001$ \\
\hline Blood hemoglobin $\mathrm{A}_{1 \mathrm{c}}(\%)$ & $7.9 \pm 2.2$ & $5.3 \pm 0.4$ & $<0.0001$ & $7.8 \pm 2.1$ & $5.3 \pm 0.4$ & $<0.0001$ \\
\hline
\end{tabular}

genes in predisposition to type 2 diabetes mellitus, the genes that contribute to genetic susceptibility to this condition remain to be identified definitively. In addition, given the ethnic differences in lifestyle and other environmental factors as well as in genetic background, it is important to examine polymorphisms related to type 2 diabetes in each ethnic group.

We previously studied the relation of 148 polymorphisms in 124 candidate genes to the prevalence of type 2 diabetes mellitus in 4853 Japanese individuals and found that $-603 \mathrm{~A} \rightarrow \mathrm{G}$ polymorphism of the coagulation factor III gene was significantly associated with this condition (16). We hypothesized that, in addition to metabolic factors such as endogenous sex hormones, genetic variants related to type 2 diabetes might differ between men and women. We thus performed a largescale association study to identify gene polymorphisms associated with the prevalence of type 2 diabetes mellitus in men and women separately.

\section{Materials and methods}

Study population. The study population comprised 4854 unrelated Japanese individuals (2688 men, 2166 women) who either visited outpatient clinics of or were admitted to one of the participating hospitals (Gifu Prefectural Gifu, Tajimi, and Gero Hotspring Hospitals; Hirosaki University Hospital; Reimeikyo Rehabilitation Hospital; and Yokohama General Hospital) between October 2002 and March 2005. The 1490 subjects (969 men, 521 women) with type 2 diabetes mellitus had a fasting plasma glucose concentration of $(6.93 \mathrm{mmol} / \mathrm{l}$ $(126 \mathrm{mg} / \mathrm{dl})$ or a blood hemoglobin $\mathrm{A}_{1 \mathrm{c}}\left(\mathrm{HbA}_{1 \mathrm{c}}\right)$ level of $\geq 6.5 \%$ (or both) or were taking antidiabetes medication. Type 2 diabetes mellitus was defined according to the criteria accepted by the World Health Organization and described previously (17). Individuals with type 1 diabetes mellitus, with maturityonset diabetes of the young, with other metabolic or endocrinologic diseases, or with severe liver or renal dysfunction were excluded from the study. Individuals taking drugs that cause secondary diabetes mellitus were also excluded.

The control subjects comprised 3364 individuals (1719 men, 1645 women) who visited the outpatient clinics of participating hospitals for an annual health checkup. They had a fasting plasma glucose concentration of $<6.05 \mathrm{mmol} / 1$ $(110 \mathrm{mg} / \mathrm{dl})$ and a blood $\mathrm{HbA}_{1 \mathrm{c}}$ level of $<5.6 \%$, and they had no history of diabetes mellitus or of taking antidiabetes medication. The study protocol complied with the Declaration of Helsinki and was approved by the Committees on the Ethics of Human Research of Mie University School of Medicine, Hirosaki University School of Medicine, Gifu International Institute of Biotechnology, and participating hospitals, and written informed consent was obtained from each participant.

Selection and genotyping of polymorphisms. We previously studied the relation of 148 polymorphisms in 124 candidate genes to the prevalence of type 2 diabetes mellitus and found that 16 polymorphisms were related to this condition on the basis of a $\mathrm{P}$ value of $<0.05$ determined by the chi-square test (16). In the present study, we examined the relation of these 16 polymorphisms to the prevalence of type 2 diabetes mellitus in men and women separately.

Venous blood (7 ml) was collected into tubes containing $50 \mathrm{mmol} / \mathrm{l}$ ethylenediaminetetraacetic acid (disodium salt), and genomic DNA was isolated with a kit (Genomix; Talent, Trieste, Italy). Genotypes of the 16 polymorphisms were determined at G\&G Science (Fukushima, Japan) by a method that combines the polymerase chain reaction and sequencespecific oligonucleotide probes with suspension array technology (Luminex, Austin, TX, USA). Primers, probes, and detailed genotyping methodology were described previously $(16,18)$.

Statistical analysis. Statistical analysis was performed for men and women separately. Clinical data were compared between subjects with type 2 diabetes mellitus and controls by the 
Table II. Polymorphisms related $(\mathrm{P}<0.05)$ to type 2 diabetes mellitus in men or in women determined by the chi-square test.

\begin{tabular}{|c|c|c|c|c|c|c|c|c|c|}
\hline \multicolumn{5}{|c|}{ Men } & \multicolumn{5}{|c|}{ Women } \\
\hline Gene & Polymorphism & dbSNP & $\mathrm{P}$ & FDR & Gene & Polymorphism & $\mathrm{dbSNP}$ & $\mathrm{P}$ & FDR \\
\hline THBS2 & $\mathrm{T} \rightarrow \mathrm{G}\left(3^{\prime} \mathrm{UTR}\right)$ & rs8089 & 0.0008 & 0.013 & PON1 & $\mathrm{A} \rightarrow \mathrm{G}$ (Arg160Gly) & rs13306698 & 0.0026 & 0.042 \\
\hline$F 3$ & $-603 \mathrm{~A} \rightarrow \mathrm{G}$ & rs1361600 & 0.0042 & 0.034 & $F 3$ & $-603 \mathrm{~A} \rightarrow \mathrm{G}$ & rs 1361600 & 0.0316 & 0.253 \\
\hline$A D I P O Q$ & $\mathrm{G} \rightarrow \mathrm{T}$ (intron 2) & rs 1501299 & 0.0081 & 0.043 & & & & & \\
\hline AKAPIO & $\mathrm{A} \rightarrow \mathrm{G}(\mathrm{Ile} 646 \mathrm{Val})$ & rs203462 & 0.0224 & 0.090 & & & & & \\
\hline$A B C A 1$ & $2583 \mathrm{~A} \rightarrow \mathrm{G}($ Ile $823 \mathrm{Met})$ & rs4149313 & 0.0326 & 0.104 & & & & & \\
\hline IPF 1 & $-108 / 3 \mathrm{G} \rightarrow 4 \mathrm{G}$ & $(\mathrm{S} 82168)^{\mathrm{a}}$ & 0.0360 & 0.096 & & & & & \\
\hline CD14 & $-159 \mathrm{C} \rightarrow \mathrm{T}$ & rs 2569190 & 0.0493 & 0.113 & & & & & \\
\hline
\end{tabular}

FDR, false discovery rate. ${ }^{a}$ An rs number in dbSNP was not detected, so the NCBI GenBank accession number is shown in parentheses.

unpaired Student's t-test. Qualitative data were compared by the chi-square test. Allele frequencies were estimated by the gene counting method, and the chi-square test was used to identify departures from Hardy-Weinberg equilibrium. In the initial screen, the genotype distribution of each polymorphism was compared between subjects with type 2 diabetes mellitus and controls by the chi-square test $(3 \times 2)$. The false discovery rate (FDR) was calculated by the method of Benjamini and Hochberg (19). Calculation of the FDR is an approach to dealing with the problems associated with multiple comparisons and provides a measure of the expected proportion of false positives among data. The FDR threshold is determined from the observed $\mathrm{P}$ value distribution and is adaptive to the signal level in data. The FDR differs from a $\mathrm{P}$ value, and much higher FDRs than $\mathrm{P}$ values can be tolerated. Initial screening of polymorphisms with the chi-square test was followed by application of multivariable logistic regression analysis and a stepwise forward selection procedure for a more rigorous evaluation of association. The FDR was calculated at each step of the statistical analysis. In the initial screen (chi-square test), the FDR was calculated from the distribution of $\mathrm{P}$ values for the 16 polymorphisms. Polymorphisms with an FDR of $<0.05$ were further examined by multivariable logistic regression analysis with adjustment for covariates, with type 2 diabetes mellitus as a dependent variable and independent variables including age, BMI, smoking status ( 0 , nonsmoker; 1, smoker), and genotype of each polymorphism. Each genotype was assessed according to dominant, recessive, and two additive (additive 1 and 2 ) genetic models, and the $\mathrm{P}$ value, odds ratio, and $95 \%$ confidence interval were calculated. The additive genetic models comprised two groups: heterozygotes versus wild-type homozygotes for the additive 1 model, and variant homozygotes versus wild-type homozygotes for the additive 2 model. We also performed a stepwise forward selection procedure to examine the effects of genotypes as well as of other covariates on type 2 diabetes mellitus. Given the multiple comparisons of genotypes with type 2 diabetes mellitus, we adopted the criterion of FDR $<0.05$ for significant association at each step of the statistical analysis. For other clinical background data, a $\mathrm{P}$ value of $<0.05$ was considered statistically significant. Statistical significance was examined by two-sided tests performed with JMP version 5.1 software (SAS Institute, Cary, NC, USA).

\section{Results}

The characteristics of the male and female subjects are shown in Table I. Among men, BMI, systolic and diastolic blood pressure, the serum concentrations of total cholesterol and triglycerides, the fasting plasma glucose concentration, and blood $\mathrm{HbA}_{1 \mathrm{c}}$ level were greater, whereas age was younger and the serum concentration of high density lipoprotein (HDL)cholesterol was lower, in subjects with type 2 diabetes mellitus than in controls. Among women, age, systolic and diastolic blood pressure, the serum concentrations of total cholesterol and triglycerides, the fasting plasma glucose concentration, and blood $\mathrm{HbA}_{1 \mathrm{c}}$ level were greater, whereas the serum concentration of HDL-cholesterol was lower, in subjects with type 2 diabetes mellitus than in controls.

Evaluation of genotype distributions by the chi-square test revealed that seven and two polymorphisms were related $(\mathrm{P}<0.05)$ to the prevalence of type 2 diabetes mellitus in men and women, respectively (Table II). Among these polymorphisms, the $\mathrm{T} \rightarrow \mathrm{G}$ (3' UTR) polymorphism of the thrombospondin 2 gene (THBS2), the $-603 \mathrm{~A} \rightarrow \mathrm{G}$ polymorphism of the coagulation factor III gene $(F 3)$, and the $\mathrm{G} \rightarrow \mathrm{T}$ (intron 2 ) polymorphism of the adipocyte, $\mathrm{C} 1 \mathrm{Q}$, and collagen domain containing (adiponectin) gene $(A D I P O Q)$ were significantly $(\mathrm{FDR}<0.05)$ associated with type 2 diabetes mellitus in men, and the $\mathrm{A} \rightarrow \mathrm{G}$ (Arg160Gly) polymorphism of the paraoxonase 1 gene (PON1) was significantly associated with this condition in women. These four polymorphisms were further analyzed for their association with this disorder.

Multivariable logistic regression analysis with adjustment for age, BMI, and smoking status revealed that the $\mathrm{T} \rightarrow \mathrm{G}$ (3' UTR) polymorphism of THBS2 (dominant, recessive, and additive 2 models), the $-603 \mathrm{~A} \rightarrow \mathrm{G}$ polymorphism of $F 3$ (recessive and additive 2 models), and the $\mathrm{G} \rightarrow \mathrm{T}$ (intron 2) polymorphism of $A D I P O Q$ (dominant, recessive, and additive 1 and 2 models) were significantly associated with type 2 diabetes mellitus in men, and that the $A \rightarrow G$ (Arg160Gly) polymorphism of PONI (dominant and additive 1 models) 
Table III. Multivariable logistic regression analysis of polymorphisms shown to be associated with type 2 diabetes mellitus in men or in women by the chi-square test.

\begin{tabular}{|c|c|c|c|c|c|c|c|c|c|}
\hline \multirow[b]{2}{*}{ Gene } & \multirow[b]{2}{*}{ Polymorphism } & \multicolumn{2}{|c|}{ Dominant } & \multicolumn{2}{|c|}{ Recessive } & \multicolumn{2}{|c|}{ Additive 1} & \multicolumn{2}{|c|}{ Additive 2} \\
\hline & & $\mathrm{P}(\mathrm{FDR})$ & OR $(95 \% \mathrm{CI})$ & $\mathrm{P}(\mathrm{FDR})$ & OR $(95 \% \mathrm{CI})$ & $\mathrm{P}(\mathrm{FDR})$ & OR $(95 \% \mathrm{CI})$ & $\mathrm{P}(\mathrm{FDR})$ & OR $(95 \% \mathrm{CI})$ \\
\hline Men & & & & & & & & & \\
\hline$T H B S 2$ & $\begin{array}{c}\mathrm{T} \rightarrow \mathrm{G} \\
\left(3^{\prime} \mathrm{UTR}\right)\end{array}$ & $\begin{array}{l}0.0248 \\
(0.043)\end{array}$ & $\begin{array}{c}0.48 \\
(0.25-0.91)\end{array}$ & $\begin{array}{l}0.0005 \\
(0.006)\end{array}$ & $\begin{array}{c}0.70 \\
(0.57-0.85)\end{array}$ & $\begin{array}{l}0.1702 \\
(0.186)\end{array}$ & & $\begin{array}{l}0.0159 \\
(0.032)\end{array}$ & $\begin{array}{c}0.46 \\
(0.24-0.86)\end{array}$ \\
\hline$F 3$ & $-603 A \rightarrow G$ & $\begin{array}{l}0.3813 \\
(0.381)\end{array}$ & & $\begin{array}{l}0.0044 \\
(0.026)\end{array}$ & $\begin{array}{c}1.74 \\
(1.19-2.55)\end{array}$ & $\begin{array}{l}0.0828 \\
(0.099)\end{array}$ & & $\begin{array}{l}0.0106 \\
(0.025)\end{array}$ & $\begin{array}{c}1.65 \\
(1.12-2.43)\end{array}$ \\
\hline$A D I P O Q$ & $\begin{array}{c}\mathrm{G} \rightarrow \mathrm{T} \\
(\text { intron 2) }\end{array}$ & $\begin{array}{l}0.0076 \\
(0.023)\end{array}$ & $\begin{array}{c}1.24 \\
(1.06-1.46)\end{array}$ & $\begin{array}{l}0.0267 \\
(0.040)\end{array}$ & $\begin{array}{c}1.36 \\
(1.03-1.77)\end{array}$ & $\begin{array}{l}0.0368 \\
(0.049)\end{array}$ & $\begin{array}{c}1.20 \\
(1.01-1.14)\end{array}$ & $\begin{array}{l}0.0069 \\
(0.028)\end{array}$ & $\begin{array}{c}1.47 \\
(1.11-1.95)\end{array}$ \\
\hline $\begin{array}{c}\text { Women } \\
\text { PON1 }\end{array}$ & $\begin{array}{c}A \rightarrow G \\
(\text { Arg } 160 \text { Gly })\end{array}$ & $\begin{array}{l}0.0010 \\
(0.002)\end{array}$ & $\begin{array}{c}1.56 \\
(1.19-2.03)\end{array}$ & $\begin{array}{l}0.3663 \\
(0.488)\end{array}$ & & $\begin{array}{l}0.0005 \\
(0.002)\end{array}$ & $\begin{array}{c}1.61 \\
(1.22-2.09)\end{array}$ & $\begin{array}{l}0.4026 \\
(0.403)\end{array}$ & \\
\hline
\end{tabular}

FDR, false discovery rate; OR, odds ratio; CI, confidence interval.

Table IV. Genotype distributions of polymorphisms associated with type 2 diabetes mellitus in men or in women.

\begin{tabular}{|c|c|c|c|}
\hline $\begin{array}{l}\text { Gene } \\
\text { symbol }\end{array}$ & Polymorphism & $\begin{array}{c}\text { Type } 2 \text { diabetes } \\
\text { mellitus }(\%)\end{array}$ & $\begin{array}{c}\text { Controls } \\
(\%)\end{array}$ \\
\hline \multicolumn{4}{|l|}{ Men } \\
\hline \multirow[t]{4}{*}{$T H B S 2$} & $\mathrm{~T} \rightarrow \mathrm{G}\left(3^{\prime} \mathrm{UTR}\right)$ & & \\
\hline & $T T$ & 84.2 & 78.8 \\
\hline & $T G$ & 14.8 & 19.1 \\
\hline & $G G$ & 1.1 & 2.2 \\
\hline \multirow[t]{4}{*}{$F 3$} & $-603 A \rightarrow G$ & & \\
\hline & $A A$ & 64.5 & 62.8 \\
\hline & $A G$ & 29.8 & 33.9 \\
\hline & $G G$ & 5.7 & 3.4 \\
\hline \multirow[t]{4}{*}{$A D I P O Q$} & $\mathrm{G} \rightarrow \mathrm{T}$ (intron 2) & & \\
\hline & $G G$ & 46.0 & 51.5 \\
\hline & $G T$ & 43.2 & 40.4 \\
\hline & $T T$ & 10.7 & 8.1 \\
\hline \multicolumn{4}{|l|}{ Women } \\
\hline \multirow[t]{4}{*}{ PON1 } & $\mathrm{A} \rightarrow \mathrm{G}$ (Arg160Gly) & & \\
\hline & $A A$ & 81.5 & 87.2 \\
\hline & $A G$ & 18.3 & 12.3 \\
\hline & $G G$ & 0.2 & 0.5 \\
\hline
\end{tabular}

was significantly associated with this condition in women (Table III). The $G$ allele of the $F 3$ polymorphism, the $T$ allele of the $A D I P O Q$ polymorphism, and the $G$ allele of the PONI polymorphism were risk factors for type 2 diabetes mellitus, whereas the $G$ allele of the THBS2 polymorphism was protective against this condition. The genotype distributions for these polymorphisms are shown in Table IV.
Finally, we performed a stepwise forward selection procedure to examine the effects of polymorphisms identified $($ FDR $<0.05)$ by the chi-square test as well as of age, BMI, and smoking status on the prevalence of type 2 diabetes mellitus (Table V). BMI, THBS2 genotype (recessive model), $A D I P O Q$ genotype (dominant model), and $F 3$ genotype (recessive model), in descending order of statistical significance, were significant and independent determinants of the prevalence of type 2 diabetes mellitus in men, and PON1 genotype (dominant model) and age significantly and independently affected the prevalence of this condition in women.

\section{Discussion}

Genetic variants that contribute to type 2 diabetes mellitus in men or women, or in both sexes, have not previously been identified definitively. We have now examined the relation of 16 polymorphisms to type 2 diabetes mellitus in men and women separately. Our large-scale association study revealed that the $\mathrm{T} \rightarrow \mathrm{G}\left(3^{\prime} \mathrm{UTR}\right)$ polymorphism of THBS2, the $\mathrm{G} \rightarrow \mathrm{T}$ (intron 2) polymorphism of $A D I P O Q$, and the $-603 \mathrm{~A} \rightarrow \mathrm{G}$ polymorphism of $F 3$ were significantly associated with the prevalence of type 2 diabetes mellitus in men, and that the $\mathrm{A} \rightarrow \mathrm{G}$ (Arg160Gly) polymorphism of PON1 was significantly associated with this condition in women. These results suggest that the association of gene polymorphisms with type 2 diabetes mellitus is sex specific in Japanese individuals.

The $T \rightarrow G\left(3^{\prime}\right.$ UTR) polymorphism of THBS2. Thrombospondins are a family of extracellular glycoproteins that participate in cell-to-cell and cell-to-matrix communication (20). Five family members (THBS1 to THBS5), each representing the product of a distinct gene, have been identified in most vertebrate species examined. THBS1 and THBS2 are trimers with a subunit molecular mass of $\sim 145 \mathrm{kDa}$, whereas THBS3 to THBS5 are pentamers with a subunit molecular mass of 
Table V. Effects of genotypes and other characteristics on type 2 diabetes mellitus in men or in women determined by a stepwise forward selection procedure.

\begin{tabular}{|c|c|c|c|c|c|c|c|}
\hline \multicolumn{4}{|c|}{ Men } & \multicolumn{4}{|c|}{ Women } \\
\hline Variable & $\mathrm{P}$ & FDR & $\mathrm{R}^{2}$ & Variable & $\mathrm{P}$ & FDR & $\mathrm{R}^{2}$ \\
\hline Body mass index & $<0.0001$ & $<0.001$ & 0.0072 & PON1 $(A A$ versus $A G+G G)$ & 0.0018 & 0.007 & 0.0041 \\
\hline$T H B S 2(T T+T G$ versus $G G)$ & 0.0005 & 0.002 & 0.0034 & Age & 0.0028 & 0.006 & 0.0037 \\
\hline$A D I P O Q(G G$ versus $G T+T T)$ & 0.0044 & 0.009 & 0.0023 & & & & \\
\hline$F 3(A A+A G$ versus $G G)$ & 0.0057 & 0.009 & 0.0022 & & & & \\
\hline
\end{tabular}

FDR, false discovery rate; $\mathrm{R}^{2}$, contribution rate.

$\sim 100 \mathrm{kDa}(21)$. Although THBS2-deficient mice exhibit abnormalities in collagen fibrillogenesis, skin fragility, and laxity of tendons and ligaments, THBS2 does not contribute directly to the structural integrity of connective tissue elements (22). The $\mathrm{T} \rightarrow \mathrm{G}$ polymorphism in the $3^{\prime}$ untranslated region (3' UTR) of THBS2 has been shown to be associated with myocardial infarction, with the $G$ allele being a protective factor against this condition $(23,24)$. We have now shown that this polymorphism of THBS2 was associated with the prevalence of type 2 diabetes mellitus in men, with the $G$ allele being protective against this condition. The underlying mechanism responsible for this association remains to be elucidated.

The $G \rightarrow T$ (intron 2) polymorphism of $A D I P O Q$. Adiponectin is an important modulator of insulin sensitivity and resistance. The plasma level of adiponectin was found to be lower in individuals with type 2 diabetes mellitus than in nondiabetic controls (25). Genetic epidemiological studies have also implicated the adiponectin gene $(A D I P O Q)$ in susceptibility to insulin resistance and type 2 diabetes mellitus $(26,27)$. $\mathrm{The} \mathrm{G} \rightarrow \mathrm{T}$ (intron 2, SNP276) polymorphism of $A D I P O Q$ was previously shown to be associated with type 2 diabetes mellitus, with the $G$ allele being a risk factor for this condition as well as being associated with increased insulin resistance and a decreased plasma adiponectin level (15). We have now shown that the $\mathrm{G} \rightarrow \mathrm{T}$ (intron 2) polymorphism of $A D I P O Q$ was associated with type 2 diabetes mellitus in men, with the $T$ allele representing a risk factor for this condition. Although the reason for the difference in the risk allele between the previous (15) and present studies is not clear, it is possible that this polymorphism is in linkage disequilibrium with other polymorphisms actually responsible for type 2 diabetes mellitus, given that it is located in an intron and may not be functional.

The $-603 A \rightarrow G$ polymorphism of F3. F3 (tissue factor or tissue thromboplastin) is a $47-\mathrm{kDa}$ transmembrane glycoprotein, which, in response to binding of factor VIIa, activates coagulation factor $\mathrm{X}$ by converting it to factor $\mathrm{Xa}$ and thereby initiates the extrinsic coagulation cascade. Although F3 is normally not expressed in circulating leukocytes or endothelial cells, transcription of $F 3$ is induced in these cells by proinflammatory cytokines, growth factors, shear forces, or balloon injury of the vessel wall (28). The expression of F3 was shown to be higher in monocytes from individuals with diabetes mellitus than in those from nondiabetic controls (29). Although similar numbers of cell-derived microparticles were found in individuals with well-controlled, uncomplicated type 2 diabetes mellitus and nondiabetic controls, a higher proportion of microparticles derived from $\mathrm{T}$ helper cells, granulocytes, and platelets exposed F3 on their surface in the former group (30). The plasma concentration of F3 was also higher in individuals with type 2 diabetes mellitus than in nondiabetic controls; furthermore, it was higher in diabetic individuals with cardiovascular disease than in those without this condition, suggesting that F3 levels are related to vascular complications $(31,32)$. We have now shown that the $-603 \mathrm{~A} \rightarrow \mathrm{G}$ polymorphism of $F 3$ was associated with the prevalence of type 2 diabetes mellitus in men, with the $G$ allele representing a risk factor for this condition.

The $A \rightarrow G$ (Arg160Gly) polymorphism of PON1. Serum paraoxonase 1 (PON1) is a calcium-dependent esterase that catalyzes the hydrolysis of organophosphates and is widely distributed among organs, including the liver, kidneys, and intestine. It is also present in serum in association with HDL. PON1 has been implicated in the detoxification of organophosphates and in the prevention of low-density lipoprotein (LDL) oxidation (33). PON1-deficient mice have an increased sensitivity to the toxic effects of both chlorpyrifos oxon and chlorpyrifos. HDL isolated from PON1-deficient mice was unable to prevent LDL oxidation, and both HDL and LDL isolated from these mice were more susceptible to oxidation than were the corresponding lipoproteins from wild-type littermates. Furthermore, PON1-deficient mice fed a high-fat diet were more susceptible to atherosclerosis than were wildtype littermates on the same diet (34). Serum paraoxonase activity was found to be reduced in patients with diabetes mellitus compared with that in nondiabetic controls $(35,36)$. The $A \rightarrow G(G \ln 192 \mathrm{Arg})$ polymorphism of $P O N 1$ was associated with coronary heart disease in subjects with type 2 diabetes mellitus, with the $G$ allele representing a risk factor for this condition (37). The $-107 \mathrm{~T} \rightarrow \mathrm{C}$ polymorphism in the promoter region of $P O N 1$, alone or in combination with the $A \rightarrow G$ (Gln192Arg) polymorphism, was also associated with coronary heart disease in type 2 diabetic patients (38). Our results suggest that the $\mathrm{A} \rightarrow \mathrm{G}$ (Arg160Gly) polymorphism of PON1 is significantly associated with type 2 diabetes mellitus in women, with the $G$ allele representing a risk factor for this 
condition. The molecular mechanism that underlies this association remains unclear.

Study limitations. Given the multiple comparisons of genotypes with type 2 diabetes mellitus in the present study, we adopted the criterion of FDR $<0.05$ for significant association in each step of the statistical analysis. It is not possible, however, to exclude completely potential statistical errors such as false positives. It is also possible that one or more of the polymorphisms associated with type 2 diabetes mellitus in our study are in linkage disequilibrium with polymorphisms of the same gene or other nearby genes that are actually responsible for the development of this condition. Furthermore, the relevance of the identified polymorphisms to gene transcription or to protein structure or function was not determined in the present study.

Our present results suggest that THBS2, ADIPOQ, and F3 are susceptibility loci for type 2 diabetes mellitus in men, and that $P O N 1$ is a susceptibility locus for this condition in women. Determination of the genotypes for these polymorphisms may prove informative for assessment of the genetic component of type 2 diabetes mellitus for men and women separately.

\section{Acknowledgments}

This study was supported in part by a Grant-in-Aid for Scientific Research from the Ministry of Education, Culture, Sports, Science, and Technology of Japan (no. 15209021, to Y.Y.) and by a grant from Gifu Prefectural Science and Technology Promotion Center (to Y.Y.). In addition to the authors, the following investigators and Japanese institutions participated in the study: Y. Matsuno and M. Tomita (Gifu Prefectural Gifu Hospital, Gifu); T. Hibino, T. Kameyama, K. Yajima, and M. Oguri (Gifu Prefectural Tajimi Hospital, Tajimi); S. Tanihata (Gifu Prefectural Gero Hotspring Hospital, Gero); M. Hiramoto (Hirosaki University, Hirosaki); and nursing and laboratory staff in the participating hospitals.

\section{References}

1. Stumvoll M, Goldstein BJ and van Haeften TW: Type 2 diabetes: principles of pathogenesis and therapy. Lancet 365: 1333-1346, 2005.

2. Zimmet P, Alberti KGMM and Shaw J: Global and societal implications of the diabetes epidemic. Nature 414: 782-787, 2001.

3. The Expert Committee on the Diagnosis and Classification of Diabetes Mellitus: Report of the Expert Committee on the Diagnosis and Classification of Diabetes Mellitus. Diabetes Care 26: S5-S20, 2003.

4. Rattarasarn C, Leelawattana R, Soonthornpun S, Setasuban W and Thamprasit A: Gender differences of regional abdominal fat distribution and their relationships with insulin sensitivity in healthy and glucose-intolerant Thais. J Clin Endocrinol Metab 89: 6266-6270, 2004.

5. Ding EL, Song Y, Malik VS and Liu S: Sex differences of endogenous sex hormones and risk of type 2 diabetes: a systematic review and meta-analysis. JAMA 295: 1288-1299, 2006.

6. Hanis CL, Boerwinkle E, Chakraborty R, et al: A genome-wide search for human non-insulin-dependent (type 2) diabetes genes reveals a major susceptibility locus on chromosome 2 . Nat Genet 13: 161-166, 1996.

7. Mahtani MM, Widen E, Lehto M, et al: Mapping of a gene for type 2 diabetes associated with an insulin secretion defect by a genome scan in Finnish families. Nat Genet 14: 90-94, 1996.

8. Elbein SC, Hoffman MD, Teng K, Leppert MF and Hasstedt SJ: A genome-wide search for type 2 diabetes susceptibility genes in Utah Caucasians. Diabetes 48: 1175-1182, 1999.
9. Ghosh S, Watanabe RM, Hauser ER, et al: Type 2 diabetes: evidence for linkage on chromosome 20 in 716 Finnish affected sib pairs. Proc Natl Acad Sci USA 96: 2198-2203, 1999.

10. Vionnet N, Hani El-H, Dupont S, et al: Genomewide search for type 2 diabetes-susceptibility genes in French whites: evidence for a novel susceptibility locus for early-onset diabetes on chromosome 3q27-qter and independent replication of a type 2diabetes locus on chromosome 1q21-q24. Am J Hum Genet 67: 1470-1480, 2000.

11. Vionnet N, Stoffel M, Takeda J, et al: Nonsense mutation in the glucokinase gene causes early-onset non-insulin-dependent diabetes mellitus. Nature 356: 721-722, 1992.

12. Almind K, Bjorbaek C, Vestergaard H, Hansen T, Echwald S and Pedersen O: Amino acid polymorphisms of insulin receptor substrate-1 in non-insulin-dependent diabetes mellitus. Lancet 342: 828-832, 1993

13. Altshuler D, Hirschhorn JN, Klannemark M, et al: The common PPAR $\gamma$ Pro12Ala polymorphism is associated with decreased risk of type 2 diabetes. Nat Genet 26: 76-80, 2000.

14. Horikawa Y, Oda N, Cox NJ, et al: Genetic variation in the gene encoding calpain-10 is associated with type 2 diabetes mellitus. Nat Genet 26: 163-175, 2000.

15. Hara K, Boutin P, Mori Y, et al: Genetic variation in the gene encoding adiponectin is associated with an increased risk of type 2 diabetes in the Japanese population. Diabetes 51: 536-540, 2002.

16. Yamada Y, Matsuo H, Segawa T, et al: Assessment of genetic factors for type 2 diabetes mellitus. Int J Mol Med 18: 299-308, 2006.

17. Kuzuya T, Nakagawa S, Satoh J, et al: Report of the Committee on the Classification and Diagnosis Criteria of Diabetes Mellitus. Diabetes Res Clin Pract 55: 65-85, 2002.

18. Itoh Y, Mizuki N, Shimada T, et al: High-throughput DNA typing of HLA-A, -B, -C, and -DRB1 loci by a PCR-SSOPLuminex method in the Japanese population. Immunogenetics 57: 717-729, 2005.

19. Benjamini $Y$ and Hochberg Y: Controlling the false discovery rate: a practical and powerful approach to multiple testing. J Royal Stat Soc Ser B 57: 289-300, 1995.

20. Lawler J: The functions of thrombospondin-1 and -2. Curr Opin Cell Biol 12: 634-640, 2000.

21. Bornstein P: Thrombospondins as matricellular modulators of cell function. J Clin Invest 107: 929-934, 2001.

22. Bornstein P, Armstrong LC, Hankenson KD, Kyriakides TR and Yang Z: Thrombospondin 2, a matricellular protein with diverse functions. Matrix Biol 19: 557-568, 2000.

23. Topol EJ, McCarthy J, Gabriel S, et al: Single nucleotide polymorphisms in multiple novel thrombospondin genes may be associated with familial premature myocardial infarction. Circulation 104: 2641-2644, 2001.

24. Boekholdt SM, Trip MD, Peters RJG, et al: Thrombospondin-2 polymorphism is associated with a reduced risk of premature myocardial infarction. Arterioscler Thromb Vasc Biol 22: e24-e27, 2002.

25. Hotta K, Funahashi T, Arita Y, et al: Plasma concentrations of a novel, adipose-specific protein, adiponectin, in type 2 diabetic patients. Arterioscler Thromb Vasc Biol 20: 1595-1599, 2000.

26. Kondo H, Shimomura I, Matsukawa Y, et al: Association of adiponectin mutation with type 2 diabetes: a candidate gene for the insulin resistance syndrome. Diabetes 51: 2325-2328, 2002.

27. Vasseur F, Helbecque N, Dina C, et al: Single-nucleotide polymorphism haplotypes in the both proximal promoter and exon 3 of the APMI gene modulate adipocyte-secreted adiponectin hormone levels and contribute to the genetic risk for type 2 diabetes in French Caucasians. Hum Mol Genet 11: 2607-2614, 2002.

28. Mackman N: Regulation of the tissue factor gene. FASEB J 9: 883-889, 1995.

29. Ichikawa K, Yoshinari M, Iwase M, et al: Advanced glycosylation end products induced tissue factor expression in human monocyte-like U937 cells and increased tissue factor expression in monocytes from diabetic patients. Atherosclerosis 136: 281-287, 1998.

30. Diamant M, Nieuwland R, Pablo RF, Sturk A, Smit JW and Radder JK: Elevated numbers of tissue-factor exposing microparticles correlate with components of the metabolic syndrome in uncomplicated type 2 diabetes mellitus. Circulation 106: 2442-2447, 2002. 
31. Lim HS, Blann AD and Lip GY: Soluble CD40 ligand, soluble P-selectin, interleukin-6, and tissue factor in diabetes mellitus: relationships to cardiovascular disease and risk factor intervention. Circulation 109: 2524-2528, 2004.

32. Lim HS, Chong AY, Freestone B, Blann AD and Lip GY: The effect of multi-factorial intervention on plasma von Willebrand factor, soluble E-selectin and tissue factor in diabetes mellitus: implications for atherosclerotic vascular disease. Diabet Med 22: 249-255, 2005.

33. Durrinton PN, Mackness B and Mackness MI: Paraoxonase and atherosclerosis. Arterioscler Thromb Vasc Biol 21: 473-480, 2001.

34. Shih DM, Gu L, Xia YR, et al: Mice lacking serum paraoxonase are susceptible to organophosphate toxicity and atherosclerosis. Nature 394: 284-287, 1998.
35. Abbott CA, Mackness MI, Kumar S, Boulton AJ and Durrington PN: Serum paraoxonase activity, concentration, and phenotype distribution in diabetes mellitus and its relationship to serum lipids and lipoproteins. Arterioscler Thromb Vasc Biol 11: $1812-1818,1995$.

36. Letellier C, Durou MR, Jouanolle AM, Le Gall JY, Poirier JY and Ruelland A: Serum paraoxonase activity and paraoxonase gene polymorphism in type 2 diabetic patients with or without vascular complications. Diabetes Metab 28: 297-304, 2002.

37. Pfohl M, Koch M, Enderle MD, et al: Paraoxonase 192 Gln/Arg gene polymorphism, coronary artery disease, and myocardial infarction in type 2 diabetes. Diabetes 48: 623-627, 1999.

38. James RW, Leviev I, Ruiz J, Passa P, Froguel P and Garin M-CB: Promoter polymorphism $\mathrm{T}(-107) \mathrm{C}$ of the paraoxonase PON1 gene is a risk factor for coronary artery disease in type 2 diabetic patients. Diabetes 49: 1390-1393, 2000. 